\title{
Technical and Operational Feasibility, for the business analysis, of running an Autopista Ferroviaria with Iberian track gauge between Port of Algeciras and Zaragoza-Plaza
}

\author{
Jaime Escobar de la Iglesia, Emilio Larrodé Pellicer \\ Departamento Ingeniería Mecánica. Universidad de Zaragoza \\ Instituto de Investigación en Ingeniería de Aragón (I3A) \\ Universidad de Zaragoza, Mariano Esquillor s/n, 50018, Zaragoza, Spain. \\ Tel. +34-976762319, e-mail: 309661@unizar.es
}

\section{Summary}

The aim of this study is to evaluate the feasibility to run an Autopista Ferroviaria (AF) with Iberian track gauge from a technical and operational point of view in order to analyse the business model in the short term.

\section{Introduction}

AF (Autopista Ferroviaria), is defined by the Spanish Public Works Department (Ministerio de Obras Públicas) as a combined transport in which semitrailers are transported by train in a shuttle service using specific wagons and terminals conditioning for this service according with the chosen operational typology [1]. According to this definition, it can be affirmed that, for the moment, Spain still has not a service that can be call AF in Iberian width. This study is based in the current Iberian railway line between the Port of Algeciras and Plaza (Zaragoza Logistics Platform) and its focus is determine if from a thecnical and operational perspective is feasibily that this rail line provides the enough features to be used as a AF. Therefore, the lineal and nodal infrastructure are analysing under this perspective. The first step is ensure that the technical limitations enable to travel with a set consisting of a wagon (in this study the dimensions are based on the model T-3000e used in Europe) and a semi-trailer P400. Then, the operational variables can be analized according with the obtained results.

\section{Background}

In the year 2018, the freight transport by rail in Spain is the $1,8 \%$ of the total [2]. The percentage of Spain compared with the European average and with several countries with similar characteristics in terms of GDP, size, kilometres of railway tracks is pretty small. According to Eurostat, the modal percentage rail freight transportation of Spain in 2016 was around $6 \%$, versus the $18 \%$ of Germany and the $11 \%$ of the France. Nowadays, European green policies are calling for changes that lessen the influence of the greenhouse effect. Then, make sense that the public sector invest in proyects which enhance this aspect, analysing frameworks for intermodal transport based on the studies of Machari, C., Van Hoeck, E., Pekin, E. and Van Lier, T. (2010) [3] and permit to the private sector be more competitive in terms of logistic cost and increase the utilization of the freight transportation via railway.

The selection of the railway line, object of this study, is due to the fact of the recent increasing of trading between tangerMed and the Port of Algeciras via short sea shipping saddle semi-trailers without tractor and the fact that the Port of Algeciras has two intermodal terminals. The selection was chosen based on the recommendations on Van Duin, R., and Van Ham, H. (1998) [4].

\section{Technical requirements}

The most critical features of the infrastructure, in technical terms, are expressed on table 1 . The main aspect to be considered is the physical gauge of three tunnels between Madrid and Zaragoza nevertheless, tunnels adaptations could be done or a reconversion in just one line inside the tunnel instead of the current two lines. The other aspects are secondaries and no represent a serius technical problem. Examples as a section without catenary between Algeciras and Bovadilla (nowadays the project of a new catenary installation of this section is running) and some necessary actuation in several platforms. The intermodal terminals based in the Port of Algeciras and Plaza-Zaragoza no represent any problem in order to admit the technical requirements of the analyzed set.

\section{Operational Analysis}

Once confirmed that technical requirements of the infrastructure enable run an AF between Algeciras 
and Plaza, the question to answer is how to operate. In Europe exist diferents systems in order to operate the rail motorways. The most important examples are the Lorry-Rail System (known as Modalohr) and the Rolling Road System (known as Rola) but for the features of the surface of the terminals, the current operation procedures in which are involved in the terminals and the tipology of the product (just semitrailes without tractor) imply that the optimal system chosen, for this phase of the study, is the loading and unloading of the semi-trailers with a special platform (as Nikrasa platform) using the cranes and the reach stackers that operate, currently, in the terminals. The most critical features, in operational terms, are expressed on table 2.

Moreover, the exploitation capacity of the railway track between Zaragoza-Plaza and Port of Algeciras is under capacity, as well as operational capacity of the intermodal terminals analyzed, consequently several daily frequencies could be offered.

\section{Conclusions}

On one hand, the technical issue to assume that an Autopista Ferroviaria (with Iberian track gauge) will be feaseble in Spain between Algeciras and Plaza is a reality. The limitations in the infrastructural aspects such as slopes; limitations of dynamic gauges in the tunnels; the characteristics of the catenary of the line and general features of the intermodal terminals do not limit the possibility to run the AF. Nevertheless, an important consideration must be done as a future critical variable: the bigger among of money to invest, the best scenario for commercialize the service. An example, amongst others, of this scenario is that for semi-trailers with greater height, more cargo could be carried and the service would be more competitive, but it would imply a greater investment to obtain greater clearance in the tunnels.

On the other hand, the necessary parameters for operating a shuttle-service with the chosen setting are currently running in other services around Europe,

Table 1. Technical Characteristics

\begin{tabular}{|c|c|c|c|}
\hline Features & $\begin{array}{c}\text { Limiting } \\
\text { Factor }\end{array}$ & $\begin{array}{c}\text { Operational } \\
\text { Influence }\end{array}$ & $\begin{array}{c}\text { Economical } \\
\text { Influence }\end{array}$ \\
\hline Gauge & No & Yes & Yes \\
\hline Platforms & No & No & No \\
\hline Catenary & No & No & No \\
\hline maximum Slope & No & Yes & Yes \\
\hline minimum Axle-load & No & No & Yes \\
\hline Siding length & No & Yes & Yes \\
\hline
\end{tabular}

even in Spain but with normal track gauge. The unique item that it is necessary to adequate to the Spanish regulation is the wagon. Nowadays, there is not a wagon which the properly height and dimensions with iberian track gauge with the necessary characteristiques. Nevertheless, sourced consulted, such as several wagon manufacturing companies (both in Spain and in Europe), railway operators, certification entities,... admit that will be no problem to design, manufacture and validate a wagon with the parameters expected.

The results of this study, with the hypotesis chosen, implies the feasibility; under the technical and operational point of view; of running an Autopista Ferroviaria service between the intermodal terminal based on the Port of Algeciras and the intermodal terminal based on Plaza (Zaragoza Logistics Platform). Obviously, the next step implies the study of the commercial and business aspects, perhaps the most important pieces of the puzzle. But it is a great conclusion to affirm that this step can be done.

\section{REFERENCES}

[1]. MINISTERIO DE FOMENTO (2015). Estudio para el Desarrollo de Autopistas Ferroviarias en la península ibérica.

[2]. CNMC, 2018. COMISION NACIONAL DE LOS MERCADOS Y LA COMPETENCIA (2019). Informe Anuel del Sector Ferroviario.

[3]. MACHARI, C., VAN HOECK, E., PEKIN, E. and VAN LIER, T. (2010). A decision analysis framework for intermodal transport: Comparing fuel price increases and the internalisation of external costs. Transportation Research Part A: Policy and Practice, 44(7), 550-561.

[4]. VAN DUIN, R., and VAN, HAM, H. (1998). A threestage modeling approach for the design and organization of intermodal transportation services. Systems, Man, and Cybernetics, 1998 IEEE International Conference on, 4. Pp. 4051-4056.

Table 2. Operational Characteristics

\begin{tabular}{|c|c|c|c|}
\hline Features & $\begin{array}{c}\text { Limiting } \\
\text { Factor }\end{array}$ & $\begin{array}{c}\text { Operational } \\
\text { Influence }\end{array}$ & $\begin{array}{c}\text { Economical } \\
\text { Influence }\end{array}$ \\
\hline Special Wagons & No & Yes & Yes \\
\hline Operational System & No & No & No \\
\hline Special semi-trailer & No & No & No \\
\hline $\begin{array}{c}\text { Semi-trailer height } \\
\text { be } \\
\text { Intermodal } \\
\text { Adaptation }\end{array}$ & $\begin{array}{c}\text { Yes } \\
\text { Ydald }\end{array}$ & Yes & Yes \\
\hline
\end{tabular}

Revista “Jornada de Jóvenes Investigadores del I3A”, vol. 8 (Actas de la IX Jornada de Jóvenes Investigadores del I3A -11 de diciembre de 2020). ISSN 2341-4790. 